WIDER Working Paper 2021/2

\title{
Secession and social polarization
}

Evidence from Catalonia

Laia Balcells, ${ }^{1}$ José Fernández-Albertos, ${ }^{2}$ and Alexander Kuo ${ }^{3}$

January 2021 
Abstract: Does secessionism lead to social polarization? Despite much research on independence movements, their relationship to polarization, a key mechanism theorized as increasing the chances of violent conflict, remains less understood. We argue that secessionist conflicts can polarize along both policy and ethnic group lines even when they take the form of non-violent disputes. However, polarization does not necessarily lead to violence. We explore the case of Catalonia, a region that experienced a deep secessionist crisis in the last months of 2017, using novel data from a panel survey fielded across two key time periods and embedded experiments. We find a society with great levels of affective polarization in that pro- and anti-independence advocates have strong negative views of one another. In addition, there is spillover in terms of the assessment of associated language groups. However, there is a group of moderates in between the two policy poles that limit the extent of this polarization. Contrary to common wisdom, these moderates have very stable preferences. Our results contribute to the understanding of the underexplored polarization dynamics of secessionist movements, particularly in places where high-intensity violence (i.e. terrorism, civil war) has not yet occurred.

Key words: Catalonia, conflict, independence movements, polarization, secessionism

JEL classification: D72, D74, H89, Y80

Acknowledgements: We are grateful for financial support from Duke University, Georgetown University, and the Christ Church (University of Oxford) Research Fund, and for assistance from staff at Respondi. For their helpful feedback we thank Alan Arwine, Kanisha Bond, Florian Foos, Aina Gallego, Patricia Justino, Nikitis Konstantinidis, Carolina de Miguel Moyer, Sarah Parkinson, Ruben Ruiz-Rufino, audiences at the annual meetings of the American Political Science Association, Midwest Political Science Association, and European Political Science Association, and seminar participants at the Juan March conferencia de doctores and the DC area comparative politics workshop, as well as the University of Toronto, University of Maryland, and King's College London.

This study is published within the UNU-WIDER project Inequality and governance in unstable democracies - the mediating role of trust, implemented by a consortium led by Institute of Development Studies (IDS). The support of the UK Economic and Social Research Council (ESRC) is gratefully acknowledged.

1 Department of Government, Georgetown University, Washington, DC, USA; corresponding author: laia.balcells@georgetown.edu; 2 Institute for Politics and Public Goods, Spanish National Research Council (CSIC), Madrid, Spain; ${ }^{3}$ Department of Politics and International Relations and Christ Church, Oxford University, United Kingdom

This study is published within the UNU-WIDER project Inequality and governance in unstable democracies—-the mediating role of trust, implemented by a consortium led by Institute of Development Studies.

Copyright (C) UNU-WIDER 2021

UNU-WIDER employs a fair use policy for reasonable reproduction of UNU-WIDER copyrighted content-such as the reproduction of a table or a figure, and/or text not exceeding 400 words - with due acknowledgement of the original source, without requiring explicit permission from the copyright holder.

Information and requests: publications@wider.unu.edu

ISSN 1798-7237 ISBN 978-92-9256-936-5

https://doi.org/10.35188/UNU-WIDER/2021/936-5

Typescript prepared by Joseph Laredo.

United Nations University World Institute for Development Economics Research provides economic analysis and policy advice with the aim of promoting sustainable and equitable development. The Institute began operations in 1985 in Helsinki, Finland, as the first research and training centre of the United Nations University. Today it is a unique blend of think tank, research institute, and UN agency — providing a range of services from policy advice to governments as well as freely available original research.

The Institute is funded through income from an endowment fund with additional contributions to its work programme from Finland, Sweden, and the United Kingdom as well as earmarked contributions for specific projects from a variety of donors.

Katajanokanlaituri 6 B, 00160 Helsinki, Finland

The views expressed in this paper are those of the author(s), and do not necessarily reflect the views of the Institute or the United Nations University, nor the programme/project donors. 
An enduring concern in many democracies is how to address regional autonomy or secessionist movements. Such demands pit conflicting values of territorial integrity or constitutional compliance against those of self-determination. While the current political impasse in Spain regarding the independence drive in Catalonia is the most salient example in the Western press, secessionist movements have recently been or are still relevant in many democratic or quasidemocratic countries (e.g. Canada, India, Indonesia, Russia, the United Kingdom) (Cunningham 2014; Griffiths 2016). The literature on such movements and their associated political parties has concentrated on their origins, success, and potential for violence; more recent literature has begun to consider more thoroughly the individual-level correlates of support for such movements and parties. But a key feature of these movements that remains less understood is the corresponding affective polarization or inter-group animus that can occur within the contested regions. In much of the secessionist and civil conflict literature, the existence of group polarization is assumed to be a cause of conflict, but to date proper theorization and empirical tests of how much and what forms of polarization are relevant in these contexts has been limited.

Social polarization is a problematic aspect of independence movements and counter-movements because it can escalate distrust and prevent peaceful resolution of the conflict. ${ }^{1}$ Even though polarization is a fundamental aspect of civil conflict and scholars recognize that identity activation can be endogenous to conflict (Dragojevic 2019; Fearon and Laitin 2000; Gagnon 2004; Kalyvas 2008), there is limited literature on this phenomenon in secessionist contexts, and evidence from situations where there is not yet violence is scarce.

In this paper, we test hypotheses about the existence of secession-based polarization, and present a design that permits the discrete measurement of individual-level political preferences and social polarization during an ongoing push for secession in an advanced democracy. The design builds on a straightforward theoretical proposition that policy differences over secession can be the basis of negative out-group (and positive in-group) evaluations and stereotyping; we categorize such attitudes as social or affective polarization (Mason 2015, 2018). This type of polarization is often assumed in many theoretical and empirical studies of conflict but is generally unmeasured. We argue that supporters and opposers of secession can polarize by expressing comfort (discomfort) with people who share (oppose) their territorial views. We further hypothesize the possibility of stereotyping people who support the opposing policy, as well as groups (e.g., ethnic, national, regional, religious/sectarian, linguistic, tribal) associated with the policy. We contend that those with intermediate policy preferences (i.e. moderates on the policy issue) will be less likely to exhibit such differences in affect and stereotyping. Our design and evidence draw on the literatures of secession, political polarization, and out-group stereotyping; to date, the latter two agendas have been largely separated from the first.

We use evidence from the current most salient and challenging case of secession in advanced industrial democracies, Catalonia. The crisis in Spain posed by the Catalan independence movement is arguably the most serious sustained challenge to Spanish democracy since the country's regime transition in the late 1970s. The region experienced peaceful protests as well as violent clashes between protestors and regional and national police in October 2019,

\footnotetext{
${ }^{1}$ We subscribe to existing definitions of social or affective polarization as the degree of relative affect (like or dislike) of another group. See, for example, Iyengar et al. (2012: 405-31). In the next section we differentiate the different uses of 'polarization' to motivate our hypotheses and design.
} 
predominantly in the largest cities (Barcelona, Girona, Lleida, and Tarragona), after the Supreme Court (Tribunal Constitucional) sentenced independentist leaders for sedition and other crimes. However, Catalonia is a 'negative' case of a violent civil conflict despite high tensions and state rejection of the movement (Balcells et al. 2020; Barceló 2018). Unlike cases in which secessionist campaigns have escalated into violence (e.g., Corsica, East Timor, Yugoslavia), the conflict in Catalonia has remained broadly non-violent, despite violence that has occurred at low-intensity levels, mainly in the form of police and protest violence. As some conflict scholars have emphasized (Straus 2015; Wood 2008), negative cases are particularly instructive about the causes of violence. Our study delves into the measurement and dynamics of polarization in a case that has not escalated into violent conflict using a clear design and novel data, collected at the peak of the (non-violent) conflict, that allow measurement of polarization. Evidence from the Catalan case is particularly relevant because it can support theorizing about scope conditions under which polarization can lead to violence, as it is one of the cases where violence has not yet escalated; we return to such conditions in the conclusion.

To study social polarization in Catalonia, we designed a unique, large, regionally representative survey in the region. The online survey was fielded in the period between the controversial referendum on 1 October 2017 and the extremely contested and salient regional elections in late December 2017. The elections were called by the Spanish government after the unprecedented activation of Article 155 of the Spanish Constitution that imposed direct rule from the Spanish government in response to the regional government's declaration (albeit 'non-pursuit') of independence. Independence was the main issue during that electoral campaign. As a robustness check and to assess for the persistence of such effects, we fielded a second wave in September 2018, re-interviewing over 60 per cent of the respondents. This follow-up allowed us to measure over-time variation in independence views and social polarization.

We measure support for independence, and potential affective polarization by ascertaining comfort with and assessments of fellow citizens who have various traits, chiefly their language group and their position on the independence issue. To elicit causal effects as well as to counter issues raised by social desirability and survey acquiescence bias, we embed a series of experiments that randomize the group assessed by survey participants.

We obtain the following findings. First, we find that independence supporters and opposers have both positive and negative affect for fellow supporters or opposers in the expected directions, and that they significantly stereotype the associated language groups (that is, Spanish-speaking for antiindependence positions, and Catalan-speaking for pro-independence positions). Second, these differences, or polarization, are pronounced for advocates of independence and the status quo, but are far smaller for individuals who support an intermediate autonomy option. Third, this secession-related polarization is persistent over time and is significantly greater than polarization over other salient policy areas.

The paper proceeds as follows. Section 2 summarizes the motivating literature and describes our theoretical propositions. Section 3 reviews recent events in Catalonia and puts them in historical context. Section 4 outlines the empirical strategy and presents relevant observational data, followed by a presentation of the core experimental results. Section 5 concludes by discussing the implications of our findings. 
Our study is motivated by claims in the literatures of the politics of secession movements and political polarization that have remained largely untested. Much existing research on the politics of secessionism is on cross-regional or national variation, focusing on why autonomy movements are politically successful (Cunningham 2013; Hale 2008; Sambanis and Milanovic 2014; Sorens 2005 ) or why self-determination movements may lead to political violence (Brancati 2006; Wimmer 2002). The general approach is to test national- and regional-level covariates to see which variables matter for certain outcomes at those levels, such as decentralizing institutions, the prominence of regional parties, strategies of the state, and regional wealth. A growing set of studies addresses why individuals support either greater decentralization or independence in specific cases (Amat 2012; Hierro and Queralt forthcoming; Muñoz and Tormos 2015; Rodón and Guinjoan 2018; Sarigil and Karakoc 2016; Serrano 2013). Many of these studies find that individuals who identify strongly with the region or relevant regional-ethnic group, due to family origins or aspects of the education system, are generally most supportive of autonomy or independence. Of course, given the highly correlated nature of many individual-level characteristics, disentangling those that are the most causally relevant is difficult.

These two general approaches to explaining secession, however, neglect an important research question: whether and how secessionism is linked to social division or social polarization within the originating region. If affective polarization based around secessionist views exists and is resilient, it could make both escalation into violence more likely and peaceful resolution of such conflicts more difficult. Similarly, such polarization could be a factor in sustaining secessionist movements. Once a secessionist movement begins, elites can have incentives to 'ethnicize' or nationalize the conflict so that views of the conflict further divide along group membership lines (Brancati 2006; Fearon and Laitin 2000; Rabushka and Shepsle 1972).

To motivate our hypothesis and design about secession-based polarization, we draw on two related literatures and identify their lacunae: one on civil conflict and the other on group stereotyping. Regarding the first, the relevance of social polarization to explain violent conflict or conflict escalation is clear from recent findings. These studies use cross-national evidence to find that polarization among ethnic groups is positively correlated with both the onset and the duration of civil conflict, as opposed to levels of ethnic fractionalization (Esteban and Schneider 2008). Such polarization measures are frequently constructed using individual-level data about which ethnic group people claim to be members of, and are defined such that polarization means an increased extent to which the population is clustered around a small number of distant poles; country-level polarization is most frequently measured simply as a mechanical feature of the distribution of group sizes. $^{2}$

But a persistent challenge in the measurement of polarization from these conflict studies is that the existence and degree of in-group positive affect and out-group animus-or how groupcalculated polarization is supposed to facilitate conflict-cannot be inferred from structural calculations of polarization based on demographic composition. Put simply, much of the literature linking demographic 'polarization' to the possibility of conflict assumes 'affective or social polarization' as the key variable, but does not actually measure it. Of course, much qualitative evidence indicates that conflict situations are frequently linked with negative stereotypes and

\footnotetext{
2 These studies differ regarding the emphasis on economic inequalities among groups in terms of explaining conflict outbreak. Empirical work draws on a family of political economy models where higher polarization is linked with bargaining failure. Esteban and Schneider (2008) present an overview of competing measures.
} 
grievances against groups, leading to mistrust. In his 1985 classic, Horowitz gives many examples of how ethnic conflict causes group stereotypes and mistrust (Horowitz 1985: 167-70), and recent studies find that such group views are themselves often endogenous to conflict dynamics (Dragojevic 2019; Fearon and Laitin 2000; Gagnon 2004; Kalyvas 2008). Since polarization measures are calculated on the basis of individual-level group affiliation, in a context of secessionist mobilization, such identity affiliations themselves could be the result of the shadow of conflict. It is thus challenging, if not impossible, to measure how a secessionist drive or conflict affects polarization and related group affect ex post, and thus valuable to obtain measurements of polarization in periods of tension.

In contrast to the civil conflict literature, which generally measures country-level polarization via group membership data, a long tradition in social psychology specifically measures the extent of in-group affect or out-group animus, even among groups that are non-ethnic. ${ }^{3}$ A recent contribution to this is literature on US partisanship, which documents the extremity of US affective partisan polarization. ${ }^{4}$ Mason $(2015,2018)$ shows that US identity-based partisan polarization has increased because of the greater sorting of various identity groups into partisan groups and the corresponding decline of cross-cutting identities. ${ }^{5}$ This research documents the many 'everyday' psychological and emotional individual bases of such group animi, and the ease with which ingroup identity or hostility towards out-groups can be experimentally manipulated. But most of such evidence comes from subjects in countries where group-based conflict is not on the horizon, and measurement of stereotyping as it relates to secessionism is absent. ${ }^{6}$

Given the above, it should be clear that what is needed in the study of secession dynamics is measurement of affective polarization when secession has become a salient political issue. The literature to date lacks consideration of affective polarization that can result from support for or opposition to secession. As secessionist claims relate to a fundamental view of the functioning of the polity, they are a likely basis of affective polarization, such that pro- versus anti-independence individuals will have negative assessments of those with opposing policy positions and positive assessments of those with similar positions. We also conjecture that secessionist claims themselves can shape division along associated group lines; division over secession can be correlated with corresponding polarization and stereotyping regarding evaluations of groups not directly related to independence. ${ }^{7}$

\footnotetext{
${ }^{3}$ See Miller and Torcal (2020) for a review of affective polarization in Spain, measured with feelings towards political parties.

${ }^{4}$ For a recent review, see Iyengar et al. (2019).

${ }^{5}$ We return to the relevance of social sorting in the design and conclusion, but for now our interest is in polarization based on a policy, whereas much of the recent research on affective polarization in the US is on how partisanship is not based on strong considerations of policy interests.

${ }^{6}$ A representative US example of activating group stereotypes can be seen in Wittenbrink et al. (2001). A few studies demonstrate the ease of identity-priming in areas where civil or ethnic conflict has occurred in post-conflict contexts; see Chang and Peisakhin (2019), Mashuri and Leeuwen (2018). In-depth studies of polarization processes during the escalation of conflict and outbreak of violence in the Baltics and the Balkans are to be found in Gagnon (2004) and Petersen (2002).

${ }^{7}$ Such affective polarization would indicate the extent to which support for various territorial preferences represents a meaningful group affiliation. While recent definitions of polarization distinguish ideological or policy-based polarization from affective polarization, we are interested in how support of or opposition to a particular salient policy (i.e. secession) conditions views of other citizens and encourages the formation of stereotypes. We take the policy disagreement as the starting point and basis for thinking of policy advocacy as a kind of identity that can have consequences akin to other types of group identification.
} 
Concretely, we expect that, on average, supporters of an independence policy position (whether it is pro- or anti-secession) will evaluate co-supporters most favourably and opposers least favourably. We also expect that supporters of a territorial position will evaluate the closest 'associated' ethnic group more favourably than the ethnic group that is not associated with the preferred policy position. This polarization in terms of affect and associated stereotypes is most likely to emerge among individuals who hold strong positions on the secession issue. Individuals who hold an intermediate policy position will be less likely to evaluate others holding different preferences negatively, and less likely to stereotype based on affiliated language groups. Further, we conjecture that the persistence of a group with an 'intermediate' policy position helps prevent polarization from escalating into conflict.

While the endogenous formation and hardening of group identities has been studied in violent contexts, we have little evidence of how these processes unfold in the context of secessionist conflicts that to date fall short of violence. ${ }^{8}$ As noted, most empirical evidence about group polarization dynamics has been gathered ex post, when a violent conflict has occurred or is well under way, not earlier, at times where polarization has initially increased (such as our study). The 'real time' strengthening of positions and ethnicization of a conflict are empirically challenging to identify. If territorial-policy-based polarization among groups exists, it is important to assess its magnitude, and to evaluate whether such division spills into animosity towards fellow citizens. This study contributes to the literature in this regard.

\section{Background to the Catalan case}

Contemporary Catalan nationalism has its roots in the late $19^{\text {th }}$ century (Balcells 2013). In the early 1930s, Catalonia had some autonomy within Spain, with institutions of self-rule. During the Franco dictatorship, cultural rights for national minorities in Spain (i.e. Basques, Catalans, Galicians) were repressed, and Spanish nationalism was fiercely promoted by state institutions. After the process of devolution began with the transition to democracy in the late 1970s, aspects of self-government in Catalonia were restored in a regional governance system called the 'State of the Autonomies'. Authority over healthcare and education provision, among other policies, was transferred to subnational parliaments and governments, but this form of federalism was incomplete (Beramendi 2012), mostly because of a lack of 'shared rule' institutions to guarantee the effective participation of subnational units in central policy-making. Limited tax autonomy incentivized fiscal irresponsibility, and national laws and institutions often restricted the autonomy of regional units. Contestation about revenue transfer from regions to the centre has been a longstanding issue, partly because decentralization has been uneven among regions, with the Basque Country and Navarra regions enjoying a distinct fiscal arrangement. This differential level of regional fiscal autonomy and a broader desire for increased political autonomy, along with identity concerns (including language policy) has caused tensions between the Catalan and Spanish governments (Colomer 1998).

In the early 2000s, demands for further decentralization in Catalonia accelerated, and a coalition government proposed a new Statute of Autonomy that would recognize Catalonia as a nation within Spain, institute more concrete protection of regional competences against interference from the central government, and implement a new method of allocating fiscal resources between

\footnotetext{
${ }^{8}$ In Criado et al. (2018), the authors document variation in inter-ethnic trust in Catalonia using lab experiments with university students, though their evidence dates from before independence became an explicit political campaign issue and prior to greater mobilization.
} 
Catalonia and the rest of Spain. After much negotiation, the new Statute was approved by the Catalan Parliament and the Spanish Parliament, and finally ratified in a referendum in Catalonia in June 2006. Four years later, however, in a controversial decision, the Spanish Constitutional Court declared certain provisions of this Statute unconstitutional, most notably the recognition of Catalonia as a nation and the 'competence shielding' of regional policies. In response, some Catalan political parties began to advocate for a referendum for independence, which found increased support among the population (Rico and Liñeira 2014).

The economic recession beginning in 2008 and the victory of the conservative (and more centralist) Partido Popular (PP) in the general election of 2011 likely helped increase support for independence; around half the Catalan population claimed support for independence in 2014. Some argue that this secessionist mobilization and subsequent ethnic polarization was mainly an elite-driven process (Barrio and Rodriguez-Teruel 2017); others contend that it was a bottom-up movement (Guibernau 2013). Regardless, social movements in favour of independence became stronger, evidenced by massive rallies calling for a self-determination referendum in the region. ${ }^{9}$

After the 2010 ruling, the Catalan government continued to press for negotiation with the central government for a new governance structure, and then insisted on a self-determination referendum. The Spanish government rejected this on constitutional grounds, and the Catalan government called for a plebiscitary election in 2015, or a regional parliamentary election in which proindependence forces would have as a single element at the top of their programme the unilateral pursuit of independence of the region (Orriols and Rodón 2016). The pro-independence coalition of parties under the moniker 'Together for Yes' $(\mathrm{JxSi})$ won 44.4 per cent of the votes and the proindependence extreme-left CUP won an additional 3.5 per cent, which gave pro-independence forces a majority of 71 seats in the regional parliament, though they fell short of the 50 per cent popular support threshold. Whether a mandate for independence had been obtained was therefore controversial, and the new government chose the option of pursuing a unilateral referendum of independence. The regional government passed a set of laws on 6-7 September 2017 that set a self-determination referendum for 1 October, intending to 'disconnect' Catalan legality from the Spanish system if a majority voted for independence.

Despite the Spanish Constitutional Court declaring this referendum law unconstitutional and central government warnings about legal consequences, the regional government proceeded with the referendum on 1 October. This led to an unprecedented crackdown by Spanish police forces as they attempted to shut down polling stations (Balcells et al. 2020; Barceló 2018). Scenes of police attacks on referendum voters and non-violent protesters became prominent in Western media. The crisis continued after the referendum, with the Catalan premier Carles Puigdemont declaring independence on 10 October (but revoking this declaration immediately afterwards), the Catalan Parliament voting a resolution for declaring Catalonia independent of Spain on 27 October (although with no operational effect), and the Spanish Senate quickly voting for the temporary suspension of autonomy of Catalonia, activating a Constitutional clause (Article 155) that allows the state to take control of a region if it 'fails to fulfil the obligations imposed upon it by the Constitution'. The application of Article 155 dissolved the Catalan Parliament and disbanded the Catalan government, and the central government called for new regional elections, which were held on 21 December 2017.

\footnotetext{
${ }^{9}$ On 9 November 2014, a non-binding and non-official referendum was held in collaboration with the regional government; over 80 per cent of the 2.3 million voters who participated ( 37 per cent of the electoral census) supported an independent Catalan state.
} 
In the December 2017 elections, the anti-independence party Ciudadanos (Citizens) won a plurality with 25.3 per cent of the vote. However, the three pro-independence parties, which together obtained a vote share of 48.5 per cent, secured another parliamentary majority. A proindependence government led by Quim Torra was invested in 2018, as Puigdemont remained outside the country due to an outstanding Spanish arrest warrant. While some pro-independence leaders and social activists such as Jordi Cuixart, Jordi Sanchez, Quim Forn, and Oriol Junqueras had been in prison since October or November 2017, others (such as Raul Romeva, Carme Forcadell, and Dolors Bassa), who had been freed on bail before the elections, were remanded in custody again on 23 March 2018. All of them were to be tried for sedition by the Spanish Supreme Court.

In June 2018, the PSOE leader Pedro Sánchez won a motion of no-confidence in the Spanish Congress and became President, replacing the conservative Mariano Rajoy. In October 2019, after the conviction for sedition and sentencing to between nine and thirteen years' imprisonment (depending on other related charges) of eleven politicians and two social organizers, mass demonstrations and violent protests occurred in Catalonia. In October 2020, several activists were detained for allegedly organizing some of these protests.

The lack of resolution of the Catalan conflict has ended 'consensual politics' in Catalonia, and has affected Spanish political competition; Vox, a new far-right Spanish nationalist party, substantially increased its electoral success in 2018 with national support of over 10 per cent, partly as a result of the Catalan issue. ${ }^{10}$ Negotiations between the Spanish and Catalan governments began in late 2019, but they are currently stalled due to the COVID-19 crisis.

\section{$4 \quad$ Empirical design}

The above background indicates that Catalonia is a natural and important testing ground for whether disagreement over regional territorial issues can be the basis of social polarization, and whether polarization spills over to the 'ethnicization' of the conflict through the formation of negative out-group stereotypes. Does disagreement over the independence issue affect evaluations of fellow citizens who share such views or are members of different groups? If so, to what extent are these views affected? To address these questions, we designed a survey with embedded experiments that was fielded between 11 and 20 December 2017, just prior to the regional elections. Our representative sample consisted of 2,537 residents of Catalonia aged 18 or older, fulfilling age-category and gender quotas. The online survey was fielded in Catalan or Spanish (respondents could choose the language). ${ }^{11}$ To test the stability of preferences and polarization after the election and after the re-imprisonment of the independentist leaders, we fielded a followup survey between 19 and 30 September 2018; 63 per cent of respondents to the first survey were re-interviewed in the second wave.

Across both waves, we first assessed the baseline preferences for Catalan independence. The core aspect of the design was to embed two distinct experiments designed to measure various aspects of social polarization related to independence views. In each experiment we randomly divided the sample into four groups. In the 'neighbours' comfort' experiment, we tested directly for policy-

\footnotetext{
10 https://ctxt.es/es/20191120/Politica/29662/Mariano-Torcal-ultraderecha-ideologia-nacionalismo-inmigracionVox.htm

11 The surveys were fielded by the company Respondi after we obtained IRB approval. We registered two pre-analysis plans (PAP) with EGAP. All the data files used in this paper will be made available as replication files.
} 
group affect by randomly asking respondents to assess the comfort of having one of four groups as a neighbour. In the 'stereotype' experiment, we measured group polarization spillovers by asking respondents to describe how well various positive and negative traits describe people who fall into one of four groups. In all designs the randomization masks the intent of the design, addresses problems of survey acquiescence bias, and prevents potential fatigue from addressing repetitive questions.

In Wave 2, we measured respondent territorial preferences again, and followed the same procedures as in Wave 1, assigning respondents to the same treatment groups as in Wave 1. In addition, to benchmark our results and degree of polarization, we assessed preferences on other highly divisive policies and measured stereotypes of those with the same or different policy preferences.

In our pre-treatment assessment of independence preferences, we asked individuals for their preferred political status of Catalonia. The response options were: that they prefer Catalonia to be an independent state; that it should have more autonomy; that the status quo should be kept; or that Catalonia should have less autonomy. In the first wave, 44 per cent (1,132 respondents) indicated a preference for Catalonia to be a separate state, 35 per cent wanted Catalonia to have more autonomy, 17 per cent indicated support for the status quo arrangement, and 5 per cent preferred less autonomy. We recoded to consider three broad categories: 'prefer independence', 'greater autonomy' (but not independence), and 'the status quo/less autonomy'. ${ }^{12}$ This tripartite coding of independence views is the most straightforward indicator of political views, which we use as the key moderator in our subsequent experimental analyses. ${ }^{13}$

Table A1 provides basic descriptive statistics of the sample, including independence views, language spoken at home, 2017 referendum participation, family origins, education, income, and gender. ${ }^{14}$ The focus of this study is not on the correlates of support for independence, as those have been extensively documented, ${ }^{15}$ but on the regression results of this outcome (Table A2). The table corroborates many previous studies of the sources of individual support for Catalan independence: controlling for other common demographic variables, we find a strong correlation between Catalan identity and support for independence. ${ }^{16}$

\footnotetext{
12 The status quo and less autonomy categories are merged because these are the two least frequent responses in our survey, together comprising only 20 per cent of respondents, and in the Catalan context represent very similar political stances.

${ }^{13}$ In our PAP we discuss this as the most relevant moderator, as it comes from observation of Catalan society as being divided among individuals who support independence, those who are strongly opposed to it, and those who support some intermediate solution.

${ }^{14}$ These figures do not differ from the regional population.

${ }^{15}$ A plethora of studies examine the question of who supports independence; see those discussed above.

${ }^{16}$ Catalan identity is measured in quintiles of a 1-10 scale, with higher values indicating self-identifying as more Catalan and lower values as more Spanish. Of course such identity may itself be endogenous to territorial preferences. See Table A2 for a discussion.
} 


\subsection{Experiment 1: assessing affect and affect intensity}

We start by testing whether the independence issue polarizes in terms of inter-group animus or comfort. That is, given that an individual takes a position on the independence issue, how is her view towards other people affected by their position on this issue? We consider one basic measure of such affect, and also measure affect in terms of the intensity of independence preferences among the individual's fellow citizens. We do this by measuring the amount of reported comfort or discomfort as a result of social proximity to people with differing or similar political positions, but varying the intensity of these positions. While we might expect (dis)comfort with (un)likeminded citizens, we wish to assess if such affect changes with exposure to those with more intense preferences.

To test this, we ask a question about the (dis)comfort that would be induced by having new hypothetical neighbours, and we vary the main characteristics of these hypothetical neighbours regarding their policy views and the public expression of these policy views, which is a realistic way of measuring individual preference intensity. Specifically, we ask respondents how comfortable they would be in moving to a place where most of their new neighbours (1) support the independence of Catalonia; (2) do not support the independence of Catalonia; (3) display proindependence flags; or (4) display Spanish flags. Compared with the first two conditions, the last two can be interpreted as indicative of intense preferences, as they are expressed publicly with the aim of their being known. ${ }^{17}$ This design allows a clear assessment of how much positive affect there is towards people who take different positions on the independence issue, as well as affect towards people who wish to make these preferences visible. ${ }^{18}$

Figure 1 displays the results for both waves, decomposed by individuals who are proindependence, pro-status quo, and pro-greater autonomy. ${ }^{19}$ It shows several key patterns that confirm considerable affective polarization over the independence issues. Overall, proindependence and pro-status quo individuals evaluate like-minded individuals very positively and unlike-minded individuals negatively, and they have rather symmetrical reactions in terms of their comfort. In the left panel, we consider the views of those who support independence. In the condition where the pro-independence advocates view potential neighbours who share their position, the reported mean comfort level is 93 out of 100 . The pro-independence advocates' view of hypothetical anti-independence neighbours drops to a considerably lower score of $45(\mathrm{p}<0.01)$; this score is below the neutral score of 50 . The comfort score for living with neighbours who would show the Catalan independentist flag is 91, not distinguishable from the 'baseline' high score of 93 for neighbours who support Catalan independence. Thus, the enthusiasm for those who outwardly support independence via the flag and those who are supportive of independence is not

\footnotetext{
17 The question text and treatment were: 'Suppose you were moving to a new apartment or house within your neighbourhood. How would you feel if most of your neighbours [are against the independence of Catalonia / support the independence of Catalonia / display the Catalan independentist flag / display the Spanish flag], on a scale of zero to one hundred, where zero means very uncomfortable, and one hundred means very comfortable?'

${ }^{18}$ Asking about flag display is sensible and familiar to respondents in Catalonia, as this is a practice that has become increasingly common as a result of the political conflict. In recent years, pro-independence people have popularized displaying secessionist flags (Estelada) on the balconies of apartments and houses (Parravano et al. 2015). In addition, much anecdotal evidence indicates a rise in the display of Spanish flags within Catalonia (and in other parts of Spain) since the 1 October 2017 referendum. See Tables D1 and D2 for balance tests.

${ }^{19}$ Tables B1 and B2 in Appendix B present the regression results.
} 
markedly different. Finally, for pro-independence individuals, the lowest comfort score is for neighbours who show the Spanish flag: $36(\mathrm{p}<.01)$. This score is statistically distinguishable from and lower than the anti-Catalan independence score of $45(\mathrm{p}<.01)$. Thus, for pro-independence advocates, hypothetical neighbours who display the Spanish flag pose more discomfort than those who are just anti-independence. But, again, neighbours who show the Catalan independentist flag are not more comfort-inducing than neighbours who are simply pro-independence.

Figure 1: Evaluation of potential neighbours, by territorial preferences (3 groups)

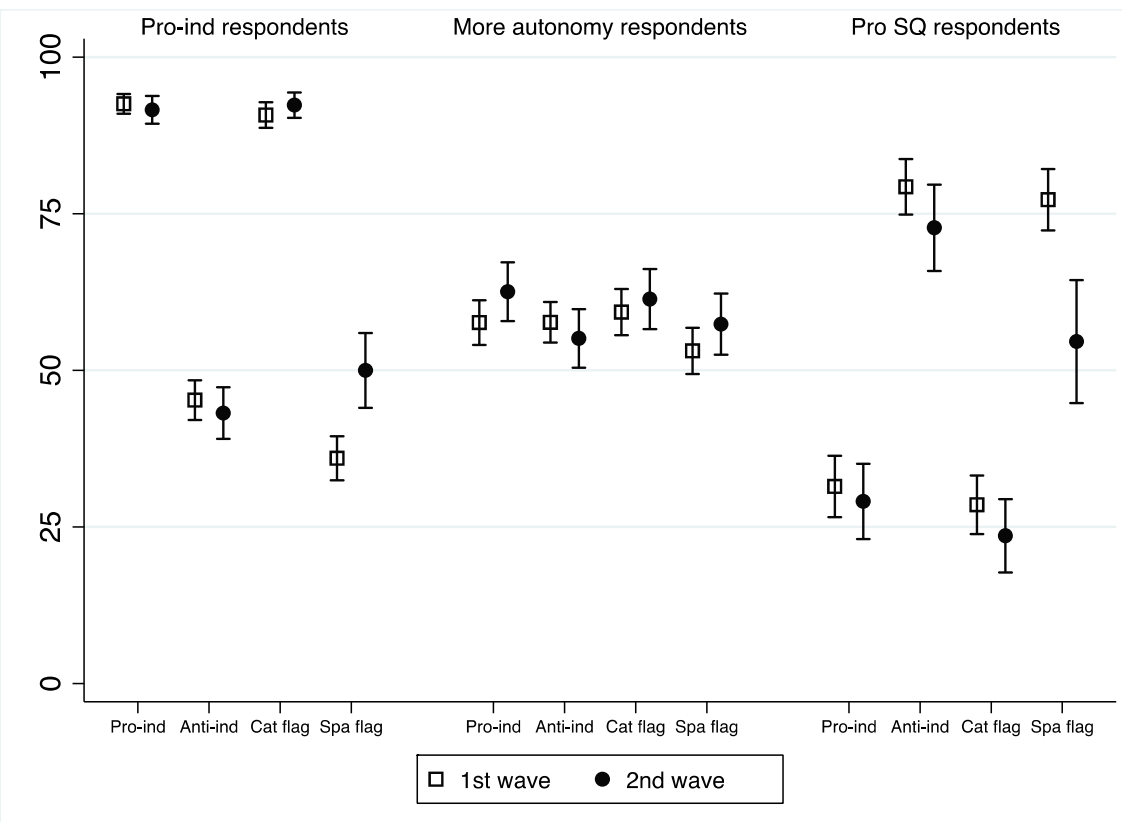

Source: authors' construction.

The right-most panel shows a similar overall trend for those who are pro-status quo (most antiindependence), although they have differences in the baseline degree of comfort. For pro-status quo respondents, there is positive affect for those who share this position; the reported comfort level for similarly anti-independence neighbours is 79 (note that this score is lower than the aforementioned pro-independence advocates' comfort with pro-independence neighbours, which was 93). At the same time, the comfort score for neighbours who show the Spanish flag is 77; this score is not statistically different from the comfort score towards those who are anti-independence. For the status quo advocates, their comfort for hypothetical pro-independence neighbours drops below the mid-point level to $32(\mathrm{p}<0.001)$. The comfort score for hypothetical neighbours who show the Catalan flag is statistically indistinct from this score, at 29. Thus, there is no difference for status quo advocates between comfort with neighbours who are supportive of an opposing position and those who are outwardly demonstrative of it. ${ }^{20}$ We note that when comparing proindependence and pro-status quo supporters, the latter show lower baseline comfort regarding their own policy supporters and flag-flyers as well as slightly lower baseline comfort for the opposing policy supporters and flag-flyers (relative to pro-independence supporters).

The middle panel, showing the results for those who support greater autonomy, reveals that such individuals have less affective polarization on the issue. These individuals do not differentiate in comfort assessments based on independence position, nor based on intensity of preferences. Across all treatments, the comfort score is consistently in the fifties and there are no statistically

\footnotetext{
${ }^{20}$ Table B1 displays the regression results where the coefficient of interest in the baseline OLS specification is the interaction term between treatment assignment $\mathrm{x}$ independence view.
} 
significant differences across the groups. This group feels similarly comfortable around the four different types of neighbours and does not differentiate among them.

These results indicate clear polarization over the secessionist issue, as pro-independence and prostatus quo supporters view the other side with less comfort and are far more comfortable with like-minded individuals. There is also relatively little difference in how each of these sides views people with more intense policy preferences (as proxied by flag display). Pro-independence individuals view potential independence flag-hanging individuals with the same comfort as they do fellow independence supporters; the equanimity in comfort holds for pro-status quo individuals. Thus, conditional on having a particular territorial view, having a neighbour with a public display of a like-minded view is not any less discomforting, an indication of polarization. However, those who support an intermediate policy position have the same, medium-level, comfort level with all groups. Figure 1 and Table $\mathrm{C} 2$ also show the over-time stability of the results of this experiment; the level of polarization is consistent. ${ }^{21}$

\subsection{Experiment 2: affect based on policy positions vs. group affiliations}

We now turn to an additional test of affective polarization, which is whether people who have a position on the independence issue have stereotypes of others with similar or different views, and whether such stereotyping extends to affiliated language groups.

We ask respondents to assess how well various character traits apply to fellow citizens, focusing on evaluations of individuals who hold similar or opposing independence views (as in the previous experiment), but we also compare such evaluations with associated language groups. We give respondents the opportunity to stereotype people holding particular policy views or speaking a particular language, and compare the stereotyping of people with independence views with that of people who speak Catalan or Spanish at home. To do so, we randomly assign respondents to one of four experimental groups, the groups being assigned to evaluate people who (1) are pro-Catalan independence; (2) are anti-Catalan independence; (3) speak mainly Catalan at home; (4) speak mainly Spanish at home. The main question text asks individuals to rate how well various adjectives characterize people who either hold a particular independence position or speak a certain language (depending on which group they are assigned to). ${ }^{22}$ For each adjective, we classify binary responses whereby $1=$ the trait describes the group extremely or very well and $0=$ all other responses. For each respondent we sum the binary indicators for the positive traits and subtract the binary indicators of the negative traits, to create a net positive evaluation score. The range is thus from -3 to $3 .{ }^{23}$ We then rescale the measure 0 to 1 , with 1 indicating maximum positive evaluation and 0

\footnotetext{
${ }^{21}$ Tables C4 and C5 present the regression results of the second wave (weighted by gender and age category); these are very similar to the unweighted results.

${ }^{22}$ The question format has been applied in other contexts on group stereotyping (for one application in the US partisan context, see Iyengar et al. 2012): 'Now we would like you to describe as best as you can what traits you think best describe people who [strongly support Catalan independence / strongly believe that Catalonia should be part of Spain / speak mostly Catalan at home / speak mostly Spanish at home]. Of course, it is difficult to generalize, but we would like you to describe them as best as you can.' The traits asked about were: open-minded, prejudiced, honest, selfish, reliable, untrustworthy — thus three generally positive and three negative traits. The response options were: not well at all, slightly well, somewhat well, very well, and extremely well.

${ }^{23}$ We code 'very well' or 'extremely well' as one and the rest zero for each adjective to indicate that the respondent positively or negatively stereotypes, to facilitate generating an index. For example, if a respondent gives a rating for all adjectives of 'very well' or 'extremely well', then the net evaluation is (3-3) $=0$, i.e. a 'neutral' evaluation (given that the respondent believes that all positive and negative traits describe the hypothetical group equally well). If a respondent rates all positive adjectives as describing the group very or extremely well, and all negative adjectives as somewhat well to not well at all, then the net score is 3 , the maximum positive evaluation of the group. We also code
} 
indicating maximum negative evaluation. ${ }^{24}$ Willingness to ascribe negative characteristics to people who have different territorial preferences would indicate polarization based on independence views, but we also wish to assess whether individuals who hold certain policy positions engage in stereotyping of certain groups.

The main quantity of interest is how individuals who have different independence views differ in their assessments of these groups. This is done by comparing the net evaluation scores of each treatment group, again sub-setting by the theoretically fundamental subgroups of proindependence, pro-status quo, and pro-autonomy supporters. ${ }^{25}$ Within each subgroup we report difference of means tests across the four treatment groups. ${ }^{26}$ In Figure 2, we present the results for the two waves of the survey.

Figure 2: Evaluation of personality traits, by territorial preferences (3 groups)

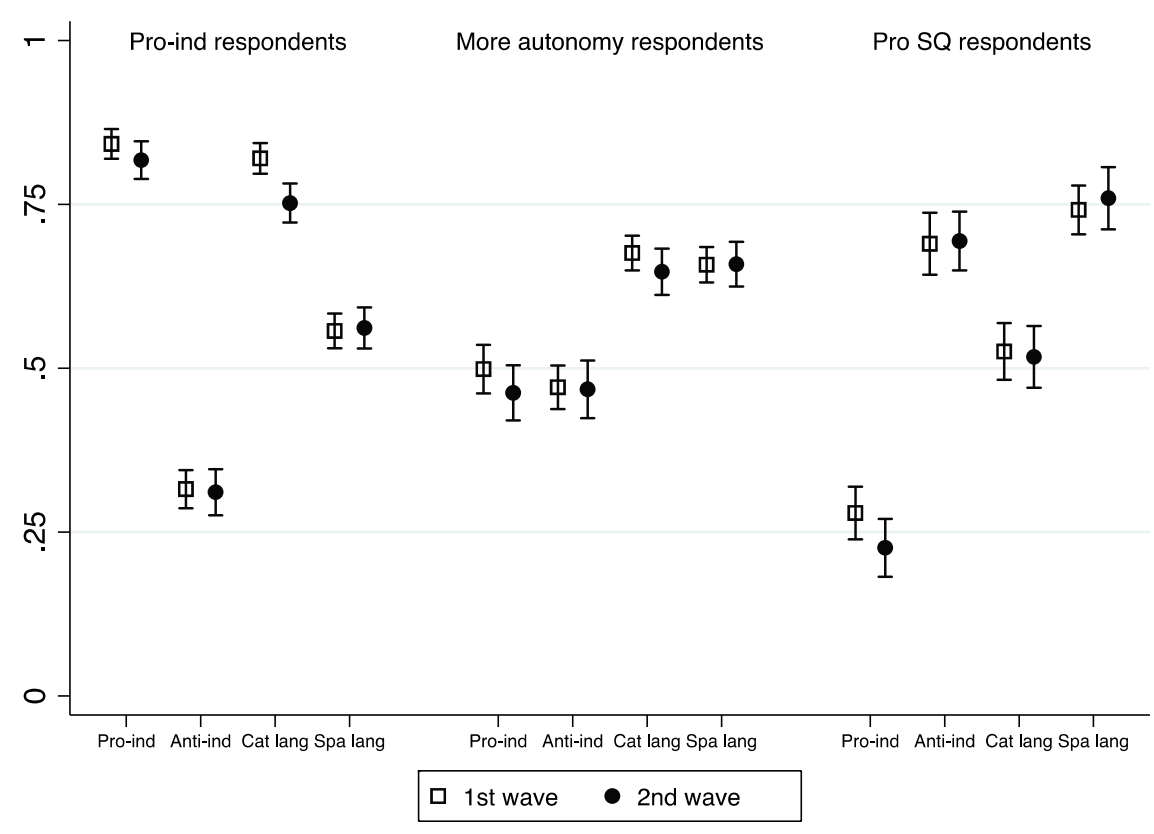

Source: authors' construction.

The differences across the groups are quite large (all differences are statistically significant at $p<.001$ ), indicating that territorial views can strongly condition evaluations of those with (dis)similar preferences, as well as evaluations of those who speak different languages at home. The left panel of the figure shows that individuals who are pro-independence evaluate very

those individuals who might wish not to stereotype by generating a separate indicator for those who answer the same for every adjective. Less than 4 per cent of respondents gave the same answer for every trait (indicating a possible aversion to stereotyping); dropping them does not change the results.

${ }^{24}$ The mean net evaluation across all groups is .59 (thus an overall positive score across the whole sample), with a standard deviation of .29 .

${ }^{25}$ For space reasons we do not present results where we compare just two groups of independence supporters across the three experiments (supporters and the rest), but they can be found in Tables B1 and B2 for interested readers.

${ }^{26}$ Table C1 displays the regression results where the coefficient of interest in the baseline OLS specification is the interaction term between treatment assignment $\mathrm{x}$ independence view. In the regression tables B1 and B2, we also present aggregated results by treatment assignment, but given that the comparison of interest is assessment of traits of people with policy positions, it makes most theoretical sense to consider the conditional role of position on the territorial issue. 
positively fellow independence supporters (a score of .84). But there is no statistically significant difference between evaluations by independence supporters of fellow supporters and of those who speak Catalan at home, as the net evaluation of the latter group is also high (.82). Independence supporters have a much lower evaluation of anti-independence people (.32), and their assessment of Spanish speakers is between these two groups at .56. Thus, individuals who support independence do differentiate in their personal evaluations of people in different groups, assessing fellow supporters and Catalan speakers similarly, with lower assessments of Spanish speakers, and making the most negative assessments of those with anti-independence positions. Among independence supporters, then, there is a strong conflation between a particular language or ethnic group and the policy position.

The right side of the figure shows similar results for those who support the status quo or prefer less autonomy. Those individuals have much higher evaluations of anti-independence people relative to pro-independence people (.69 vs. .28), and the difference between their evaluations of anti-independence people and Spanish speakers is slight (.69 vs. $.74, p<.10)$. Their evaluations of the associated language 'out-group', Catalan speakers, is lower, at .53. The general stereotypepreference ordering of pro-status quo individuals across the four groups is similar to that of proindependence individuals.

The middle panel of Figure 2 displays the experimental results for those who prefer greater autonomy but not independence. The stark result is that there are much smaller differences in these individuals' evaluations of the four groups. Pro-autonomy individuals do not differentiate between anti- and pro-independence groups (.47 vs. .50), nor between Catalan and Spanish speakers (.68 vs. .66). A notable contrast between these individuals and supporters of the two ends of the policy spectrum is that pro-autonomy individuals consistently rate members of language groups much higher than those holding particular policy positions, regardless of the policy or language group. Such individuals thus have an aversion to the negative stereotyping of members of language groups.

These results taken overall corroborate our hypotheses and are consistent with the results of the 'neighbours' experiment. Regarding the follow-up wave, as Figure 2 and Table C3 also show, there is high diachronic stability of the stereotyping across all treatment groups. This combined evidence within Wave 2 indicates that in September 2018 the polarization around the independence issue that we had captured in December 2017 was still in place. ${ }^{27}$

\subsection{Benchmarking}

Is polarization over independence distinct from that of other issues? While the theoretical focus here is the consequence of secession, a reasonable question is whether policy-based stereotyping is a more general phenomenon. To benchmark our effects and provide a robustness check, in the second wave of the survey we included additional policy questions that allowed us to compare polarization over independence to polarization over other issues that are also likely to be divisive. We essentially replicated the second experiment but instead of polarization over independence, we considered polarization over two other issues. We focused on the traditional divide that has structured political competition in Europe (the conflict over the role of the state in the economy), and one policy issue that is salient in European politics and increasingly so in Spain (immigration). ${ }^{28}$

\footnotetext{
${ }^{27}$ We find inconclusive and null results of moderators of education and length of independence support on affect evaluations; these moderators were not discussed in the PAPs. The results are available upon request.

${ }^{28}$ Fiscal and migration issues are increasingly polarizing Spanish society. See, for example, Miller (2020).
} 
Early in the survey, we assessed respondents' views on immigration and state intervention, and coded them as supporting or opposing immigration, or supporting or opposing state intervention. Later in the survey we measured the dependent variable as in the stereotype treatment, only we asked about views of people who have particular opinions on immigration and state intervention. ${ }^{29}$ For the immigration trait assessment, we randomly assign the respondent with .5 probability to one of the following questions: Now we would like you to describe as best as you can what traits you think best describe people who believe that immigration laws and policies should be [more / less] restrictive so that people from poorer countries find it [harder / easier] to settle in our country. Of course, it is difficult to generalize, but we would like you to describe as best as you can.' The traits listed are the same as those asked in Experiment 2, with the same coding procedures followed to generate a net positive evaluation score. For the state intervention trait assessment, we conducted the exact same design, but asked instead about 'people who believe that the state should intervene [more / less] in the economy with taxes and regulations.'

Our comparison of net trait evaluations for the Catalan independence issue and language groups with net trait evaluations on the immigration and state intervention issues is depicted in Figure 3.

Figure 3: Evaluation of personality traits, by policy preferences (2 groups), Wave 2

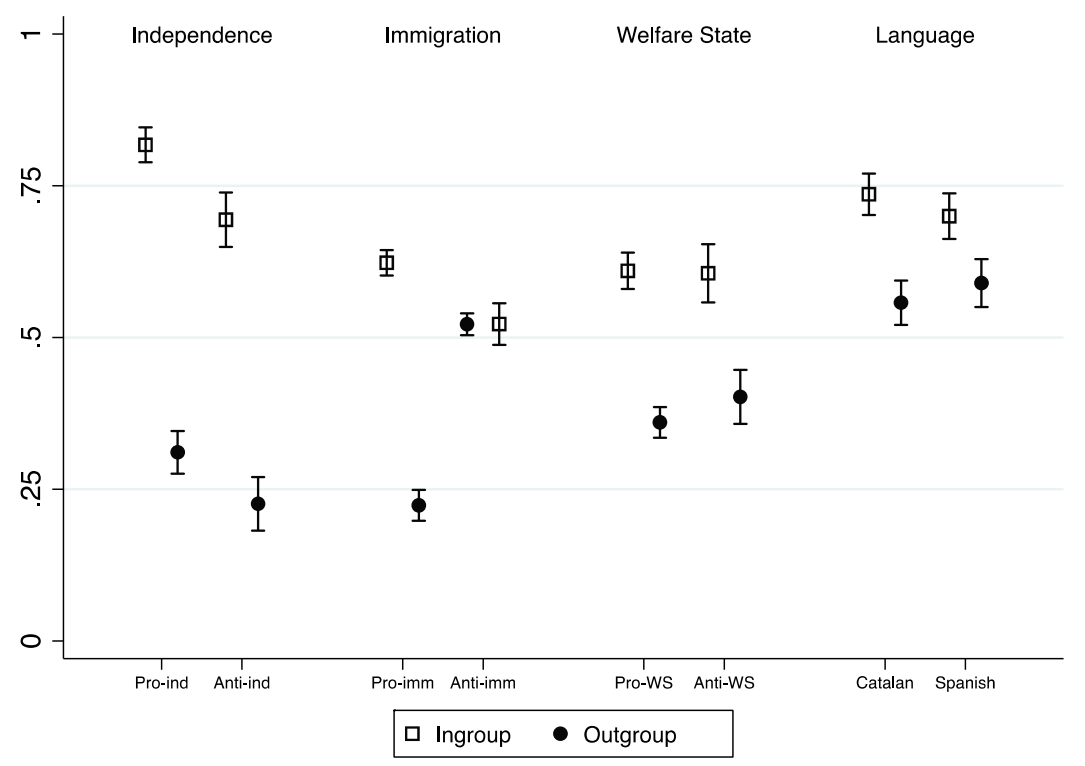

Source: authors' construction.

The figure shows that, while there is of course some polarization regarding both immigration views and state intervention views, the degree of polarization for these policy issues is somewhat less than that for the independence issue, and in some cases more than that of polarization regarding evaluations of language groups. ${ }^{30}$ This comparison is most relevant if we consider people at different ends of the independence spectrum. For example, for pro-independence individuals, the

\footnotetext{
${ }^{29}$ The text of the immigration question reads, 'How much do you agree or disagree with the following statement? "Immigration laws and policies should be more restrictive so that people from poorer countries find it harder to settle in our country"?' The text of the state intervention question reads, 'How much do you agree or disagree with the following statement: "The state should intervene more in the economy with taxes and regulations in order to achieve a fairer society"?' Response options and coding are the same as for Experiment 2. These questions were located at disparate points in the survey.

${ }^{30}$ Note that here the baseline category to assess stereotyping in the language dimension is the language of the respondent, not her policy preferences as in Figure 2.
} 
difference in net evaluations of fellow pro- versus anti-independence individuals is about .51; this is greater than the difference in how pro-immigration individuals view those who are pro- and anti-immigration (.40). But, if we compare the other relevant benchmark of evaluations by proindependence people of the two language groups, while there is a difference of about 19 (the difference in pro-independence people's evaluations of Catalan versus Spanish speakers), this difference is less than the gap for pro-immigration individuals' net evaluations. We note, however, from our test that anti-immigration individuals do not view pro- versus anti-immigration individuals differently, and thus for all comparisons pro- and anti-independence individuals have more polarized views than anti-immigration individuals. We obtain similar results regarding polarization along support for state intervention: independence polarization is substantively greater than polarization over state intervention, and state intervention polarization is greater than that of attitudes towards language groups. ${ }^{31}$

\section{Discussion}

While much research on civil conflict documents the role of polarization in escalating or prolonging such conflict, a constructivist approach to studying relevant affective polarization 'as it happens' is empirically difficult. In the secession literature, there is little measurement of social polarization in places where such movements are salient but high-intensity violence has not (yet) occurred. In this article, we propose straightforward hypotheses of why and which individuals are likely to polarize along secessionist lines, and design and test these in a salient case. The results of our two-wave survey and embedded experiments indicate polarization around the secessionist issue in Catalonia, which we measure by comfort and affect towards people who hold similar or different positions, and affect towards associated language groups. ${ }^{32}$ The results of our second survey wave also show that there is persistence in such division. The claims and findings in this article have broad implications for the comparative study of secessionism, conflict, and group polarization. ${ }^{33}$ Our findings also provide crucial evidence that connects claims about the demographic structure of a society, polarization, and conflict. This is a contribution, given that such claims rely on affect towards the in-group versus the out-group.

We emphasize that we are not claiming that the secessionist movement caused social polarization, as such a claim would require detailed over-time data on the measures described here, which do not exist. ${ }^{34}$ Nor do we contest that individual ethnic or nationalist sentiments may be explaining both secessionist drives and discriminatory attitudes. We show that the policy of secession, once pursued, can create a form of identity that has social spillovers in terms of affect and stereotyping. Further, this polarization displays over-time persistence and is greater than that of standard, nonterritorial-oriented policy disagreements. However, we also show that those with intermediate policy views (i.e. moderates) have smaller differences in affect towards people with distinct

\footnotetext{
31 Table E1 displays these estimation results.

32 This finding is consistent with what Criado et al. (2018) find regarding the effect of independentist mobilization on trust among Catalan university students belonging to different language groups.

${ }^{33}$ For a similar study regarding the polarizing effect of the Brexit referendum, see Hobolt et al. (forthcoming).

34 There are no data on stereotyping prior to 2017 except for one survey commissioned by the Centro de Investigaciones Sociologicas in 1994 (CIS Study 2123), but this study does not capture the relevant stereotyping in Catalonia that is the subject of this study and is not longitudinal.
} 
territorial views (and people that are members of different language groups) and are less prone to stereotyping those with such differences.

Regarding scope conditions, our results could be applicable to cases in which, as in the case of Spain, secessionist movements are met with countermanding responses from the state. We would expect less polarization in cases in which the state is more open to accommodation to secessionists' demands (for example, the case of Scotland in the United Kingdom prior to Brexit). Nonetheless, social polarization could also be measured in these latter contexts and set in comparison with the former.

Another key conclusion of our research is the relevance of homogeneity within blocs of support for or opposition to secession. We find that the pro-independence bloc in Catalonia is internally much more homogeneous than the anti-independence bloc. The anti-independence bloc includes those who want Catalonia to have more autonomy within Spain and those who want to either maintain the status quo or reduce the autonomy of Catalonia. We find that the latter subgroup displays similar patterns to the pro-independence group, showing some symmetry in social polarization between two more extreme positions. The middle (i.e. pro-autonomy) group does not exhibit the same patterns of social polarization as the other two. Much of the existing literature on polarization in cross-national conflict studies ignores the fact that individuals may identify with more than one group or may have ambivalent preferences towards secessionist and unionist movements (Hierro and Gallego 2018). Critically, the consequences of polarization may depend on the direction of such cross-pressured individuals (Muñoz and Tormos 2015; Rodón and Guinjoan 2018). As per Mason's perspective on the rise of US partisan polarization, while such individuals currently have cross-cutting identities, further government actions may change the relative weight of these identities and group sorting. Both the events around the October 2017 referendum and the October 2019 riots and concerns about civil unrest in Catalonia speak to the relevance of government actions in affecting this middle group of citizens (Balcells et al. 2020; Barceló 2018). Furthermore, our results suggest that the preferences and views of an intermediate group may help explain the lack of escalation and 'negative' cases of conflict.

\section{References}

Amat, F. (2012). 'Party Competition and Preferences for Inter-Regional Redistribution'. South European Society and Politics, 17(10): 449-65. https://doi.org/10.1080/13608746.2012.701897

Balcells, L. (2013). 'Mass Schooling and Catalan Nationalism'. Nationalism and Ethnic Politics, 19(4): 467-86. https://doi.org/10.1080/13537113.2013.847602

Balcells, L., S. Dorsey, and J. Tellez (2020). 'Repression and Dissent in Contemporary Catalonia'. British Journal of Political Science (online). https://doi.org/10.1017/S0007123420000307

Barceló, J. (2018). 'Batons and Ballots: the Effectiveness of State Violence in Fighting against Catalan Separatism'. Research \& Politics, 5(2): 1-9. https://doi.org/10.1177/2053168018781747

Beramendi, P. (2012). The Political Geography of Inequality: Regions and Redistribution. New York: Cambridge University Press. https://doi.org/10.1017/CBO9781139042796

Brancati, D. (2006). 'Decentralization: Fueling the Fire or Dampening the Flames of Ethnic Conflict and Secessionism?. International Organization, 60(Summer): 651-85. https://doi.org/10.1017/S002081830606019X

Chang, H.I., and L. Peisakhin (2019). 'Building Cooperation among Groups in Conflict: an Experiment on Intersectarian Cooperation in Lebanon'. American Journal of Political Science, 63(1): 146-62. https://doi.org/10.1111/ajps.12397 
Colomer, J. (1998). 'The Spanish "State of Autonomies": Non-Institutional Federalism'. West European Politics, 21: 40-52. https://doi.org/10.1080/01402389808425270

Criado, H., F. Herreros, L. Miller, and P. Ubeda (2018). 'The Unintended Consequences of Political Mobilization on Trust. The Case of the Secessionist Process in Catalonia'. Journal of Conflict Resolution, 62(2): 231-53. https://doi.org/10.1177/0022002717723433

Cunningham, K.G. (2014). Inside the Politics of Self-Determination. Oxford: Oxford University Press. https://doi.org/10.1093/acprof:oso/9780199364909.001.0001

Cunningham, K.G., E. Massetti, and A.H. Schakel (2013). 'Ideology Matters: Why Decentralisation Has a Differentiated Effect on Regionalist Parties' Fortunes in Western Democracies'. European Journal of Political Research, 52(10): 797-821. https://doi.org/10.1111/1475-6765.12015

Dragojevic, M. (2019). Amoral Communities. Collective Crimes in Time of War. Ithaca, NY: Cornell University Press. https://doi.org/10.7591/9781501739835

Esteban, J.-M., and G. Schneider (2008). 'Polarization and Conflict: Theoretical and Empirical Issues'. Journal of Peace Research, 45: 131-41. https://doi.org/10.1177/0022343307087168

Fearon, J., and D. Laitin (2000). 'Violence and the Social Construction of Ethnic Identity'. International Organization, 54(Autumn): 845-77. https://doi.org/10.1162/002081800551398

Gagnon, C. (2004). The Myth of Ethnic War. Serbia and Croatia in the 1990s. Ithaca, NY: Cornell University Press.

Griffiths, R.D. (2016). Age of Secession: The International and Domestic Determinants of State Birth. New York: Cambridge University Press. https://doi.org/10.1017/CBO9781316676479

Hale, H. (2008). The Foundations of Ethnic Politics. Separatism of States and Nations in Eurasia and the World. New York: Cambridge University Press. https://doi.org/10.1017/CBO9780511790669

Hierro, M.J., and A. Gallego (2018). 'Identities in between: Political Conflict and Ethnonational Identities in Multicultural States'. Journal of Conflict Resolution, 62(7): 1314-39. https://doi.org/10.1177/0022002716682593

Hierro, M.J., and D. Queralt (forthcoming). 'The Divide Over Independence: Explaining Preferences for Secession in an Advanced Democracy'. American Journal of Political Science.

Hobolt, S., T.J. Leeper, and J. Tilley (forthcoming). 'Divided by the Vote: Affective Polarization in the Wake of the Brexit Referendum'. British Journal of Political Science.

Horowitz, D. (1985). Ethnic Groups in Conflict. Berkeley and Los Angeles: University of California Press.

Iyengar, S., G. Sood, and Y. Lelkes (2012). 'Affect, Not Ideology: a Social Identity Perspective on Polarization’. Public Opinion Quarterly, 76(3): 405-31. https://doi.org/10.1093/poq/nfs038

Iyengar, S., Y. Lelkes, M. Levendusky, N. Malhotra, and S.J. Westwood (2019). 'The Origins and Consequences of Affective Polarization in the United States'. Annual Review of Political Science, 22(5): 129-46. https://doi.org/10.1146/annurev-polisci-051117-073034

Kalyvas, S.N. (2008). 'Ethnic Defection in Civil War'. Comparative Political Studies, 41(8): 1043-68. https://doi.org/10.1177/0010414008317949

Mashuri, A., and E. van Leeuwen (2018). 'Predicting Support for Reconciliation in Separatist Conflict'. Personality and Social Psychology Bulletin, 44(2): 173-85. https://doi.org/10.1177/0146167217733076

Mason, L. (2015). 'I Disrespectfully Agree: the Differential Effects of Partisan Sorting on Social and Issue Polarization'. American Journal of Political Science, 59(1): 128-45. https://doi.org/10.1111/ajps.12089

Mason, L. (2018). Uncivil Agreement: How Politics Became Our Identity. Chicago, Ill: University of Chicago Press. https://doi.org/10.7208/chicago/9780226524689.001.0001

Miller, L. (2020). 'Polarización en España: más divididos por ideología e identidad que por políticas públicas’. EsadeEcPol Insight, 18 (online). Available at: https://dobetter.esade.edu/es/polarizacionespana?_wrapper_format=html (accessed 3 December 2020). 
Miller, L., and M. Torcal (2020). 'Veinticino años de polarización afectiva en España'. The Conversation, 31 October. Available at: https://theconversation.com/veinticinco-anos-de-polarizacion-afectiva-enespana-149237 (accessed 3 December 2020).

Muñoz, J., and R. Tormos (2015). 'Economic Expectations and Support for Secession in Catalonia: Between Causality and Rationalization'. European Political Science Review, 7(5): 315-41. https://doi.org/10.1017/S1755773914000174

Orriols, L., and T. Rodón (2016). 'The 2015 Catalan Election: The Independence Bid at the Polls'. South European Society and Politics, 21(6): 359-81. https:// doi.org/10.1080/13608746.2016.1191182

Parravano, A., J.A. Noguera, P. Hermida, and J. Tena-Sánchez (2015). 'Field Evidence of Social Influence in the Expression of Political Preferences: The Case of Secessionists Flags in Barcelona'. PLoS ONE, 10(5): e0125085. https://doi.org/10.1371/journal.pone.0125085

Petersen, R. (2002). Understanding Ethnic Violence. Fear, Hatred, and Resentment in Twentieth-Century Eastern Europe. New York: Cambridge University Press. https://doi.org/10.1017/CBO9780511840661

Rabushka, A., and K.A. Shepsle (1972). Politics in Plural Societies: A Theory of Democratic Instability. Columbus, $\mathrm{OH}$ : Merrill.

Rico, G., and R. Liñeira (2014). 'Bringing Secessionism into the Mainstream: the 2012 Regional Election in Catalonia'. South European Society and Politics, 19(5): 257-80. https://doi.org/10.1080/13608746.2014.910324

Rodón, T., and M. Guinjoan (2018). 'When the Context Matters: Identity, Secession and the Spatial Dimension in Catalonia'. Political Geography, 63(3): 75-87. https://doi.org/10.1016/j.polgeo.2018.01.004

Sambanis, N., and B. Milanovic (2014). 'Explaining Regional Autonomy Differences in Decentralized Countries'. Comparative Political Studies, 47(11): 1830-55. https://doi.org/10.1177/0010414013520524

Sarigil, Z., and E. Karakoc (2016). 'Who Supports Secession? The Determinants of Secessionist Attitudes among Turkey's Kurds'. Nations and Nationalism, 22(4): 325-46. https://doi.org/10.1111/nana.12150

Serrano, I. (2013). 'Just a Matter of Identity? Support for Independence in Catalonia'. Regional and Federal Studies, 23: 523-45. https://doi.org/10.1080/13597566.2013.775945

Sorens, J. (2005). 'The Cross-Sectional Determinants of Secessionism in Advanced Democracies'. Comparative Political Studies, 38(4): 304-26. https://doi.org/10.1177/0010414004272538

Wimmer A. (2002). Nationalist Exclusion and Ethnic Conflict. New York: Cambridge University Press. https://doi.org/10.1017/CBO9780511490415

Wittenbrink, B., C.M. Judd, and B. Park (2001). 'Spontaneous Prejudice in Context: Variability in Automatically Activated Attitudes'. Journal of Personality and Social Psychology, 81(11): 815-27. https://doi.org/10.1037/0022-3514.81.5.815 
Appendix A: Descriptive statistics and baseline preferences

Table A1: Descriptive statistics

\begin{tabular}{|c|c|c|c|c|c|c|}
\hline Variable & Obs & Mean & Std. Dev. & Min & $\operatorname{Max}$ & $\%$ \\
\hline \multicolumn{7}{|l|}{ Wave 1} \\
\hline Female & 2,537 & & & & & $48.88 \%$ \\
\hline Age & 2,537 & 43.85 & 14.60 & 18 & 85 & \\
\hline Education_1 & 2,537 & & & & & $5.91 \%$ \\
\hline Education_2 & 2,537 & & & & & $37.64 \%$ \\
\hline Education_3 & 2,537 & & & & & $56.44 \%$ \\
\hline Language Catalan & 2,537 & & & & & $36.30 \%$ \\
\hline Language Spanish & 2,537 & & & & & $33.50 \%$ \\
\hline Language Catalan\&Spanish & 2,537 & & & & & $25.70 \%$ \\
\hline Household Size & 2,537 & 2.79 & 1.16 & 1 & 9 & \\
\hline Income & 2,537 & $2,612.34$ & $1,370.42$ & 0 & 5,500 & \\
\hline Employed & 2,537 & & & & & $65.94 \%$ \\
\hline Catalan Identity & 2,537 & 6.83 & 2.55 & 1 & 10 & \\
\hline Catalan Republic & 2,537 & & & & & $44.42 \%$ \\
\hline More Autonomy & 2,537 & & & & & $35.55 \%$ \\
\hline Status Quo & 2,537 & & & & & $16.63 \%$ \\
\hline Less Autonomy & 2,537 & & & & & $3.39 \%$ \\
\hline \multicolumn{7}{|l|}{ Wave 2} \\
\hline Variable & Obs & Mean & Std. Dev. & Min & $\operatorname{Max}$ & $\%$ \\
\hline Female & 1,721 & & & & & $47.30 \%$ \\
\hline Age & 1,721 & 46.53 & 14.40 & 18 & 86 & \\
\hline Education_1 & 1,676 & & & & & $5.07 \%$ \\
\hline Education_2 & 1,676 & & & & & $37.77 \%$ \\
\hline Education_3 & 1,676 & & & & & $57.16 \%$ \\
\hline Language Catalan & 1,676 & & & & & $37.77 \%$ \\
\hline Language Spanish & 1,676 & & & & & $32.58 \%$ \\
\hline Language Catalan\&Spanish & 1,676 & & & & & $25.78 \%$ \\
\hline Household Size & 1,676 & 2.75 & 1.14 & 1 & 9 & \\
\hline Income & 1,721 & $2,545.58$ & $1,354.91$ & 0 & 5,500 & \\
\hline Employed & 1,721 & & & & & $93.43 \%$ \\
\hline Catalan Identity & 1,721 & 6.74 & 2.72 & 0 & 10 & \\
\hline Catalan Republic & 1,721 & & & & & $46.54 \%$ \\
\hline More Autonomy & 1,721 & & & & & $33 \%$ \\
\hline Status Quo & 1,721 & & & & & $15.28 \%$ \\
\hline Less Autonomy & 1,721 & & & & & $5.17 \%$ \\
\hline Support Immigration & 1,721 & & & & & $55.20 \%$ \\
\hline
\end{tabular}

Source: authors' construction. 
Table A2: Correlates of territorial preferences, Wave 1

\begin{tabular}{|c|c|c|c|c|}
\hline & (1) & (2) & (3) & (4) \\
\hline \multirow[t]{2}{*}{ Female } & $-0.025^{\star}$ & $-0.028^{\star \star \star}$ & $-0.14^{*}$ & $-0.26^{\star \star \star}$ \\
\hline & $(0.014)$ & $(0.010)$ & $(0.078)$ & $(0.093)$ \\
\hline \multicolumn{5}{|l|}{ Age category } \\
\hline \multirow[t]{2}{*}{ Age 35-44 } & -0.013 & $-0.024^{*}$ & -0.061 & $-0.24^{\star}$ \\
\hline & $(0.020)$ & $(0.014)$ & $(0.11)$ & $(0.13)$ \\
\hline \multirow[t]{2}{*}{ Age $45-54$} & $-0.049^{\star \star}$ & $-0.069 * \star \star$ & $-0.25^{\star \star}$ & $-0.62^{\star \star \star}$ \\
\hline & $(0.020)$ & $(0.015)$ & $(0.11)$ & $(0.13)$ \\
\hline \multirow[t]{2}{*}{ Age 55+ } & -0.0031 & $-0.056^{\star \star \star}$ & -0.013 & $-0.54^{\star \star \star}$ \\
\hline & $(0.019)$ & $(0.014)$ & $(0.10)$ & $(0.13)$ \\
\hline \multicolumn{5}{|l|}{ Inc quintile } \\
\hline \multirow[t]{2}{*}{ Quintile 2} & $0.049 * \star$ & 0.019 & $0.24^{* *}$ & 0.16 \\
\hline & $(0.022)$ & $(0.016)$ & $(0.12)$ & $(0.14)$ \\
\hline \multirow[t]{2}{*}{ Quintile 3} & $0.050^{\star *}$ & 0.013 & 0.27 ** & 0.100 \\
\hline & $(0.022)$ & $(0.016)$ & $(0.12)$ & $(0.14)$ \\
\hline \multirow[t]{2}{*}{ Quintile 4} & 0.032 & 0.0046 & 0.19 & 0.025 \\
\hline & $(0.023)$ & $(0.017)$ & $(0.13)$ & $(0.15)$ \\
\hline \multirow[t]{2}{*}{ Quintile 5} & 0.037 & 0.017 & 0.17 & 0.16 \\
\hline & $(0.024)$ & $(0.017)$ & $(0.13)$ & $(0.16)$ \\
\hline \multirow[t]{2}{*}{ Unemployed } & -0.0095 & -0.012 & -0.059 & -0.035 \\
\hline & $(0.027)$ & $(0.020)$ & $(0.15)$ & $(0.18)$ \\
\hline \multirow[t]{2}{*}{ High educ } & 0.015 & 0.016 & 0.093 & 0.13 \\
\hline & $(0.015)$ & $(0.011)$ & $(0.083)$ & $(0.098)$ \\
\hline \multicolumn{5}{|l|}{ Family origins } \\
\hline \multirow[t]{2}{*}{ Born in Cat/parents not } & $0.15^{\star \star \star}$ & -0.016 & $0.73^{\star \star \star}$ & -0.12 \\
\hline & $(0.022)$ & $(0.017)$ & $(0.12)$ & $(0.14)$ \\
\hline \multirow[t]{2}{*}{ Born in Cat/1 parent } & $0.26^{\star \star \star}$ & 0.017 & $1.30^{\star \star \star}$ & 0.14 \\
\hline & $(0.021)$ & $(0.016)$ & $(0.11)$ & $(0.14)$ \\
\hline \multirow[t]{2}{*}{ All born in Cat } & $0.38^{\star \star \star}$ & 0.014 & $2.05^{\star \star \star}$ & 0.072 \\
\hline & $(0.019)$ & $(0.015)$ & $(0.11)$ & $(0.14)$ \\
\hline \multicolumn{5}{|l|}{ Catalan ID } \\
\hline \multirow[t]{2}{*}{ Cat ID $2^{\text {nd }}$ quintile } & & $0.12^{\star \star \star}$ & & $1.07^{\star \star \star}$ \\
\hline & & $(0.031)$ & & $(0.27)$ \\
\hline \multirow[t]{2}{*}{ Cat ID $3^{\text {rd }}$ quintile } & & $0.29 \star \star \star$ & & 2.27 *** \\
\hline & & $(0.022)$ & & $(0.22)$ \\
\hline \multirow[t]{2}{*}{ Cat ID $4^{\text {th }}$ quintile } & & $0.65^{\star \star \star}$ & & $4.67^{\star \star \star}$ \\
\hline & & $(0.024)$ & & $(0.24)$ \\
\hline \multirow[t]{2}{*}{ Cat ID $5^{\text {th }}$ quintile } & & $0.84^{\star \star \star}$ & & $6.80^{\star \star \star}$ \\
\hline & & $(0.024)$ & & $(0.27)$ \\
\hline \multirow[t]{2}{*}{ _cons } & $0.38^{\star \star \star}$ & $0.13^{\star * \star}$ & & \\
\hline & $(0.025)$ & $(0.024)$ & & \\
\hline \multirow[t]{2}{*}{ cut1 } & & & $-0.34^{\star \star}$ & $1.18^{\star \star \star}$ \\
\hline & & & $(0.14)$ & $(0.23)$ \\
\hline cut2 & & & $1.51^{\star \star \star}$ & $4.28^{\star \star \star}$ \\
\hline & & & $(0.14)$ & $(0.25)$ \\
\hline$N$ & 2,519 & 2,519 & 2,519 & 2,519 \\
\hline$R^{2}$ & 0.161 & 0.570 & & \\
\hline
\end{tabular}

Note: standard errors in parentheses. Models 1-2 OLS estimation. Models 3-4 ordered logistic estimation. * $p<0.10,{ }^{* *} p<0.05,{ }^{* \star *} p<0.01$.

Source: authors' construction. 
Table A2 presents correlates of territorial preferences. As noted in the main text, the dependent variable is support for status quo or less autonomy, more autonomy, or independence. Columns 1-2 present OLS estimations where the territorial preferences (status quo or less autonomy, more autonomy, independence) are recoded $0-1 \quad(0=$ status quo or less, $.5=$ more autonomy, $1=$ independence). Columns 3-4 present ordered logistic estimations. All models consider the role of female gender, education (coded as at least some post-secondary schooling 1 and the rest 0 ), age group $(18-34,35-44,45-54,55+)$, unemployment status, income quintile, and family origin. For family origin, we use binary indicators of the following categories: respondent and both parents born outside Catalonia, respondent born in Catalonia and both parents outside, respondent and one parent born in Catalonia, and both parents and respondent born in Catalonia. Unless otherwise noted, all variables are coded as binary indicators of each level, with the lowest level set as the baseline.

Models 2 and 4 consider the additional role of self-identified Catalan versus Spanish identity; this was assessed on a 1-10 scale with higher values indicating more Catalan self-identification. We display quintiles of this variable. Self-professed Catalan identification is strongly correlated with greater autonomy and independence preferences. Once this variable is controlled for, family origin is no longer precisely estimated. We caution of course that self-professed identification might be the result of territorial preferences.

The ordered-logit models indicate that intermediate Catalan identity (quintile 3) is strongly correlated with support for the intermediate autonomy option; with the other demographic variables at means the predicted probability of this option is .6 (that of independence support is .1 and that of the status quo is .3). 
Appendix B: Estimation results, Wave 1

Table B1: OLS regression showing moderating effect of independence and treatment assignment on affect towards hypothetical neighbours, Wave 1

(1)

Baseline

(Reference: Antiindy neighbours)

Pro-independence neighbours

Independentist flag neighbours

Spanish flag neighbours

Pro-independence (PI)

PI*Pro-independence neighbours

$\mathrm{PI}^{\star}$ Independentist flag neighbours

$\mathrm{PI}$ Spanish flag neighbours

Support status quo (SQ)

SQ*Pro-independence neighbours

SQ*Independentist flag neighbours

SQ*Spanish flag neighbours

Constant

$N$

$R^{2}$
$11.3^{* \star *}$

(1.78)

$11.4^{\star \star *}$

$-5.47^{\star \star \star}$
(2)

Two groups

(Reference: Anti-

indy neighbours,

respondent antiindy)

$-16.2^{\star \star \star}$

(1.99)

$-17.5^{\star \star \star}$

(2.05)

$-2.77$

(2.04)

$-19.6^{\star \star \star}$

(2.17)

$63.5^{\star \star \star}$

(3.02)

$63.01^{\star \star \star}$

(3.04)

$-6.38^{* *}$

(3.07)
(3)

Three groups

(Reference: Anti-indy neighbours,

respondent proautonomy)

0.13

1.46

$-4.57^{\star}$

$-12.41^{\text {** }}$

$47.17^{\text {kᄎ }}$

$44.06^{\text {*k }}$

$-20.99^{\text {** }}$

(2.88)

$46.7^{\star \star \star}$

$-51.9^{\star \star \star ~}$

3.15

(4.00)

$57.6^{\star \star \star}$

(1.68)

2,551

2,551

(1.44)

2,551

0.411

Note: standard errors in parentheses. $\mathrm{N}$ for each treatment group is: 621 (anti-independence), 664 (proindependence), 633 (display Catalan flags), 619 (display Spanish flags). ${ }^{*} p<0.10,{ }^{* \star} p<0.05,{ }^{\star \star *} p<0.01$. Source: authors' construction. 
Table B2: OLS regression showing moderating effect of independence and treatment assignment on affect towards individuals supporting policies and associated language groups, Wave 1

\begin{tabular}{|c|c|c|c|}
\hline & (1) & (2) & (3) \\
\hline & $\begin{array}{c}\text { Baseline } \\
\text { (Reference: } \\
\text { evaluate Spanish } \\
\text { speaker) }\end{array}$ & $\begin{array}{c}\text { Two groups } \\
\text { (Reference: evaluate } \\
\text { Spanish speaker, } \\
\text { anti-indy) }\end{array}$ & $\begin{array}{c}\text { Three groups } \\
\text { (Reference: evaluate } \\
\text { Spanish speaker, } \\
\text { pro-autonomy) }\end{array}$ \\
\hline \multirow[t]{2}{*}{ Evaluate pro-independence } & $-0.030^{\star \star}$ & $-0.27^{\star \star \star}$ & $-0.16^{\star \star \star}$ \\
\hline & $(0.015)$ & $(0.018)$ & $(0.021)$ \\
\hline \multirow[t]{2}{*}{ Evaluate anti-independence } & $-0.19^{\star \star \star}$ & $-0.13^{\star \star \star}$ & $-0.19^{\star \star \star}$ \\
\hline & $(0.015)$ & $(0.018)$ & $(0.022)$ \\
\hline \multirow[t]{2}{*}{ Evaluate Catalan speaker } & $0.078^{\star \star \star}$ & $-0.064^{\star \star \star}$ & 0.018 \\
\hline & $(0.015)$ & $(0.018)$ & $(0.021)$ \\
\hline \multirow[t]{2}{*}{ Pro-independence (PI) } & & $-0.13^{\star \star \star}$ & $-0.10^{\star \star \star}$ \\
\hline & & $(0.019)$ & $(0.020)$ \\
\hline \multirow[t]{2}{*}{$\mathrm{PI}$ Evaluate pro-independence } & & $0.56^{\star \star \star}$ & $0.44^{\star \star \star}$ \\
\hline & & $(0.027)$ & $(0.029)$ \\
\hline \multirow[t]{2}{*}{$\mathrm{PI}^{\star}$ Evaluate anti-independence } & & $-0.11^{\star \star \star}$ & $-0.055^{\star}$ \\
\hline & & $(0.027)$ & $(0.029)$ \\
\hline \multirow[t]{2}{*}{ PI^Evaluate Catalan speaker } & & $0.33^{* \star \star}$ & $0.24^{\star \star \star}$ \\
\hline & & $(0.027)$ & $(0.029)$ \\
\hline \multirow[t]{2}{*}{ Support status quo (SQ) } & & & $0.084^{\star \star \star}$ \\
\hline & & & $(0.026)$ \\
\hline \multirow[t]{2}{*}{ SQ*Evaluate pro-independence } & & & $-0.31^{\star \star \star}$ \\
\hline & & & $(0.036)$ \\
\hline \multirow[t]{2}{*}{ SQ*Evaluate anti-independence } & & & $0.13^{\star \star \star}$ \\
\hline & & & $(0.037)$ \\
\hline \multirow[t]{2}{*}{ SQ*Evaluate Catalan speaker } & & & $-0.23^{\star \star \star}$ \\
\hline & & & $(0.036)$ \\
\hline \multirow[t]{2}{*}{ Constant } & $0.63^{\star \star \star}$ & $0.68^{\star \star \star}$ & $0.66^{\star \star \star}$ \\
\hline & $(0.011)$ & $(0.013)$ & $(0.015)$ \\
\hline$N$ & 2,551 & 2,551 & 2,551 \\
\hline$R^{2}$ & 0.111 & 0.324 & 0.372 \\
\hline
\end{tabular}

Note: standard errors in parentheses. $\mathrm{N}$ for each treatment group is: 623 (pro-independence), 647 (antiindependence), 618 (speak Catalan), 649 (speak Spanish). ${ }^{*} p<0.10,{ }^{* *} p<0.05,{ }^{* \star *} p<0.01$.

Source: authors' construction. 
Appendix C: Descriptive statistics and estimation results, Wave 1 vs Wave 2

Table C1: Differences between waves in key moderator (territorial views) and outcomes

\begin{tabular}{|c|c|c|c|c|}
\hline Treatment assignment & $\begin{array}{c}\text { Mean } \\
\text { change } \\
\text { All }\end{array}$ & $\begin{array}{l}\text { Mean } \\
\text { change } \\
\text { Pro-indy }\end{array}$ & $\begin{array}{c}\text { Mean } \\
\text { change } \\
\text { Pro-SQ }\end{array}$ & $\begin{array}{c}\text { Mean } \\
\text { change } \\
\text { Pro-auto }\end{array}$ \\
\hline Independence position & 0.02 & & & \\
\hline Pro-indy trait evaluation & -0.02 & -0.04 & -0.03 & 0 \\
\hline Anti-indy trait evaluation & 0.01 & 0.01 & -0.02 & 0.04 \\
\hline Cat language speaker evaluation & -0.04 & -0.05 & -0.01 & -0.03 \\
\hline Span language speaker evaluation & 0.004 & 0.02 & 0 & 0 \\
\hline Pro-cat indy neighbours & -2.3 & -0.6 & -3.9 & -1 \\
\hline Cat flag neighbours & -0.3 & -1.6 & -5.8 & 2.7 \\
\hline Anti-indy neighbours & 1.4 & 1.6 & 3.2 & 1 \\
\hline Span flag neighbours & -2.7 & 1.2 & -9.1 & -2.8 \\
\hline Support independence if minimal economic cost & & -0.02 & & \\
\hline Support independence if medium economic cost & & 0.01 & & \\
\hline Support independence if high economic cost & & -0.02 & & \\
\hline Support independence if social cost & & -0.01 & & \\
\hline Prevent independence if minimal economic cost & & & 0.02 & -0.07 \\
\hline Prevent independence if medium economic cost & & & -0.03 & 0 \\
\hline Prevent independence if high economic cost & & & 0.13 & 0 \\
\hline Prevent independence if social cost & & & 0.03 & -0.07 \\
\hline
\end{tabular}

Note: table reports first difference of dependent variable outcomes by treatment group, with the latter 3 columns conditioning on individuals who had no change in independence position across sample ( $85 \%$ of sample). All variables are scaled 0-1 except for neighbour assessments, which are scaled 0-100.

Source: authors' construction.

Table C2: Changes in comfort towards hypothetical neighbours between the two waves

\begin{tabular}{lllll}
\hline & $\begin{array}{c}\text { Treatment: } \\
\text { Pro-independence } \\
\text { neighbour }\end{array}$ & $\begin{array}{c}\text { (1) } \\
\text { Treatment: } \\
\text { Anti-independence } \\
\text { neighbour }\end{array}$ & $\begin{array}{c}\text { (3) } \\
\text { Treatment: } \\
\text { Catalan } \\
\text { independentist flag }\end{array}$ & $\begin{array}{c}\text { (4) } \\
\text { Treatment: } \\
\text { Spanish national } \\
\text { flag }\end{array}$ \\
Pro-independence & -3.67 & 0.35 & -0.30 & 4.89 \\
& $(2.72)$ & $(3.35)$ & $(2.42)$ & $(3.21)$ \\
Constant & $-6.48^{*}$ & -4.15 & -1.93 & -4.45 \\
& $(3.34)$ & $(4.30)$ & $(2.96)$ & $(3.93)$ \\
$N$ & 2.02 & & & -3.73 \\
$R^{2}$ & $(2.07)$ & -0.97 & 1.87 & $(2.44)$ \\
\hline
\end{tabular}

Note: standard errors in parentheses; ${ }^{\star} p<0.10,{ }^{* \star} p<0.05,{ }^{* \star \star} p<0.01$.

Source: authors' construction. 
Table C3: Change in people's evaluation towards groups between the two waves

(1)

Evaluate proindependence people

Pro-independence

$-0.050^{*}$

(0.028)

Pro-status quo

$-0.053$

(0.033)

Constant

$N$

$R^{2}$ 0.011

(0.021)

379

0.010
(2)

Evaluate antiindependence people

$-0.036$

(0.038)

$-0.052$

(0.047)

0.042

(0.030)

405

0.004
(3)

Evaluate

Catalan-speaking Spanish-speaking people

\section{$-0.0072$}

(0.026)

0.038

(0.033)

$-0.041^{\star \star}$

(0.019)

368

0.006
0.020

(4)

Evaluate people

(0.027)

$-0.0091$

(0.034)

2.2e-10

(0.020)

394 0.003

Note: standard errors in parentheses; ${ }^{*} p<0.10,{ }^{* \star} p<0.05,{ }^{* \star} p<0.01$.

Source: authors' construction. 
Table C4: OLS regression showing moderating effect of independence and treatment assignment on affect towards hypothetical neighbours, Wave 2 (weighted results)

\begin{tabular}{|c|c|c|c|}
\hline & $\begin{array}{c}\text { (1) } \\
\text { Comfort }\end{array}$ & $\begin{array}{c}\text { (2) } \\
\text { Comfort }\end{array}$ & $\begin{array}{c}\text { (3) } \\
\text { Comfort }\end{array}$ \\
\hline Pro-independence neighbours & $\begin{array}{r}15.4^{\star \star \star} \\
(2.17)\end{array}$ & $\begin{array}{c}8.60^{\star \star \star} \\
(3.09)\end{array}$ & $\begin{array}{r}9.38^{\star \star *} \\
(3.14)\end{array}$ \\
\hline Independentist flag neighbours & $\begin{array}{r}15.4^{\star \star \star} \\
(2.21)\end{array}$ & $\begin{array}{r}8.55^{\star \star *} \\
(3.24)\end{array}$ & $\begin{array}{r}9.85^{\star \star *} \\
(3.26)\end{array}$ \\
\hline Spanish flag neighbours & $\begin{array}{r}-6.61^{\star \star \star} \\
(2.09)\end{array}$ & $\begin{array}{r}-1.81 \\
(3.11)\end{array}$ & $\begin{array}{r}-1.06 \\
(3.15)\end{array}$ \\
\hline Pro-independence (PI) & & $\begin{array}{r}-11.0^{\star \star \star} \\
(2.95)\end{array}$ & $\begin{array}{r}-10.5^{\star \star \star} \\
(3.00)\end{array}$ \\
\hline PI*Pro-independence neighbours & & $\begin{array}{r}39.6^{\star \star \star} \\
(3.80)\end{array}$ & $\begin{array}{r}38.9^{\star \star \star *} \\
(3.87)\end{array}$ \\
\hline PI*Independentist flag neighbours & & $\begin{array}{r}40.4^{\star * *} \\
(3.90)\end{array}$ & $\begin{array}{r}39.0^{\star \star *} \\
(3.93)\end{array}$ \\
\hline PI*Spanish flag neighbours & & $\begin{array}{r}-8.21^{\star *} \\
(4.12)\end{array}$ & $\begin{array}{r}-8.70^{\star *} \\
(4.19)\end{array}$ \\
\hline Support status quo (SQ) & & $\begin{array}{r}20.4^{\star \star \star} \\
(4.02)\end{array}$ & $\begin{array}{r}20.2^{\star \star \star} \\
(4.06)\end{array}$ \\
\hline SQ*Pro-independence neighbours & & $\begin{array}{r}-54.6^{\star \star \star} \\
(5.32)\end{array}$ & $\begin{array}{r}-54.5^{\star \star \star} \\
(5.37)\end{array}$ \\
\hline SQ*Independentist flag neighbours & & $\begin{array}{r}-58.3^{\star \star \star} \\
(5.42)\end{array}$ & $\begin{array}{r}-59.9^{\star \star \star *} \\
(5.47)\end{array}$ \\
\hline SQ*Spanish flag neighbours & & $\begin{array}{l}-6.61 \\
(5.80)\end{array}$ & $\begin{array}{l}-7.23 \\
(5.82)\end{array}$ \\
\hline Female & & & $\begin{array}{c}2.06^{\star} \\
(1.22)\end{array}$ \\
\hline Secondary educ & & & $\begin{array}{l}0.054 \\
(3.26)\end{array}$ \\
\hline Post-secondary & & & $\begin{array}{r}0.27 \\
(3.27)\end{array}$ \\
\hline Unemployed & & & $\begin{array}{r}1.05 \\
(2.45)\end{array}$ \\
\hline Income decile & & & $\begin{array}{r}0.39 \\
(0.25)\end{array}$ \\
\hline Born in Cat, parents not & & & $\begin{array}{r}-1.28 \\
(2.10)\end{array}$ \\
\hline Born in Cat, 1 parent also & & & $\begin{array}{r}-2.83 \\
(1.98)\end{array}$ \\
\hline Born in Cat, 2 parents also & & & $\begin{array}{r}-1.19 \\
(1.80)\end{array}$ \\
\hline _cons & $\begin{array}{r}52.9^{\star \star \star} \\
(1.46)\end{array}$ & $\begin{array}{r}54.2^{\star \star \star} \\
(2.22)\end{array}$ & $\begin{array}{r}51.7^{\star \star \star} \\
(4.10)\end{array}$ \\
\hline$N$ & 1,710 & 1,710 & 1,665 \\
\hline$R^{2}$ & 0.085 & 0.449 & 0.456 \\
\hline
\end{tabular}

Note: standard errors in parentheses. Main reference category for column 1 = 'anti-independence neighbours' treatment. Main reference categories for columns 2-3 = 'anti-independence neighbour' treatment category and 'support autonomy' respondents. Reference categories for column 3 demographic variables are: male, primaryeducation only, employed, not born in Catalonia. ${ }^{*} p<0.10,{ }^{* \star} p<0.05,{ }^{* \star *} p<0.01$.

Source: authors' construction. 
Table C5: OLS regression showing moderating effect of independence and treatment assignment on stereotyping of individuals supporting policies and associated language groups, Wave 2 (weighted results)

(1)

Evaluate pro-independence

Evaluate anti-independence

Evaluate Catalan speaker

Pro-independence (PI)

$\mathrm{PI}$ Evaluate pro-independence

PI*Evaluate anti-independence

PI*Evaluate Catalan speaker

Support status quo (SQ)

SQ*Evaluate pro-independence

SQ*Evaluate anti-independence

SQ^Evaluate Catalan speaker

Female

Secondary educ

Post-secondary

Unemployed

Income decile

Born in Cat, parents not

Born in Cat, 1 parent also

Born in Cat, 2 parents also

_cons

$N$

$R^{2}$
(2)

(3)
Net stereotype score

-0.20 ***

(0.029)

$-0.20^{\star \star \star}$

(0.030)

$-0.0099$

(0.026)

-0.099 ***

(0.024)

$0.46^{\star \star \star}$

(0.036)

$-0.048$

(0.039)

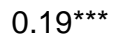

(0.035)

$0.11^{\star \star *}$

(0.030)

$-0.35^{\star \star \star}$

(0.044)

$0.13^{\star \star \star}$

(0.046)

$-0.24^{\star \star \star}$

(0.044)
Net stereotype score

-0.20 ***

(0.029)

-0.20 ***

(0.030)

$-0.011$

(0.026)

$-0.097^{\star \star \star}$

(0.025)

0.46 *ᄎ*

(0.036)

$-0.050$

(0.039)

0.19 *ᄎ*

(0.035)

0.10 ***

(0.030)

$-0.35^{\star \star \star ~}$

(0.044)

$0.13^{\star \star \star ~}$

(0.046)

$-0.24^{\star \star \star}$

(0.044)

$0.025^{\text {** }}$

(0.012)

0.054

0.014

(0.026)

$0.0041^{*}$

(0.0022)

0.0015

0.000078

$-0.010$

(0.017)

$0.62^{\star \star \star *}$

(0.037)

1,665

0.380

Note: standard errors in parentheses. Main reference category for column 1 = 'evaluate Spanish speakers' treatment. Main reference categories for columns 2-3 = 'evaluate Spanish speakers' treatment category and 'support autonomy' respondents. Reference categories for column 3 demographic variables are: male, primaryeducation only, employed, not born in Catalonia. ${ }^{*} p<0.10,{ }^{* \star} p<0.05,{ }^{* \star *} p<0.01$.

Source: authors' construction. 
Appendix D: Balance tests

Table D1: Treatment assignment, neighbours' experiment (Wave 1)

\begin{tabular}{|c|c|c|c|c|}
\hline & (1) & (2) & (3) & (4) \\
\hline & $\begin{array}{c}\text { Anti-indy } \\
\text { neighbours }\end{array}$ & $\begin{array}{c}\text { Pro-indy } \\
\text { neighbours }\end{array}$ & Catalan flags & Spanish flags \\
\hline \multirow[t]{2}{*}{ Support auto } & 0.024 & 0.12 & -0.15 & 0.0088 \\
\hline & $(0.10)$ & $(0.10)$ & $(0.10)$ & $(0.11)$ \\
\hline \multirow[t]{2}{*}{ Support SQ } & -0.097 & 0.069 & -0.067 & 0.093 \\
\hline & $(0.13)$ & $(0.12)$ & $(0.12)$ & $(0.12)$ \\
\hline \multirow[t]{2}{*}{ Female } & 0.14 & $-0.20^{* *}$ & 0.063 & 0.00011 \\
\hline & $(0.094)$ & $(0.092)$ & $(0.093)$ & $(0.094)$ \\
\hline \multirow[t]{2}{*}{ Unemployed } & -0.095 & -0.11 & 0.063 & 0.14 \\
\hline & $(0.18)$ & $(0.18)$ & $(0.18)$ & $(0.18)$ \\
\hline \multirow[t]{2}{*}{ Decile } & -0.0024 & -0.028 & 0.012 & 0.019 \\
\hline & $(0.018)$ & $(0.017)$ & $(0.018)$ & $(0.018)$ \\
\hline \multirow[t]{2}{*}{ Education } & 0.014 & -0.011 & 0.048 & -0.052 \\
\hline & $(0.081)$ & $(0.079)$ & $(0.081)$ & $(0.081)$ \\
\hline \multirow[t]{2}{*}{ Constant } & $-1.20^{\star \star \star}$ & $-0.82^{\star \star \star}$ & $-1.25^{\star \star \star}$ & $-1.14^{\star \star \star}$ \\
\hline & $(0.22)$ & $(0.21)$ & $(0.22)$ & $(0.22)$ \\
\hline$N$ & 2,519 & 2,519 & 2,519 & 2,519 \\
\hline
\end{tabular}

Note: standard errors in parentheses; ${ }^{\star *} p<0.05$, ${ }^{\star \star \star} p<0.01$.

Source: authors' construction. 
Table D2: Treatment assignment, stereotypes experiment (Wave 1)

Pro-indy

Support auto

Support SQ

Unemployed

Decile

Education

Constant
(1)

0.021

(0.11)

0.16

(0.12)

$-0.14$

(0.094)

(2)

Anti-indy

$-0.17$

(0.10)

$-0.17$

(0.12)

0.019

(0.093)

0.13

(0.17)

(0.17)

0.0072

(0.018)

$-0.093$

(0.080)

$-0.91^{\star \star \star}$

(0.22)

2,519

(0.22)
(3)

(4)

Speak Catalan Speak Spanish

0.098

0.060

(0.11)

(0.10)

0.16

$-0.15$

(0.12)

(0.13)

0.082

0.037

(0.094)

(0.093)

$-0.27$

$-0.087$

(0.19)

$(0.18)$

0.0079

$-0.0082$

$(0.018)$

$(0.017)$

$-0.023$

0.024

$(0.081)$

$(0.080)$

$-1.21^{\star * \star}$

$-1.09^{\star \star *}$

$(0.22)$

$(0.22)$

2,519

2,519

Note: standard errors in parentheses; ${ }^{\star \star} p<0.05,{ }^{\star \star \star} p<0.01$.

Source: authors' construction. 
Appendix E: Benchmark tests, Wave 2

Table E1: Stereotype evaluations by treatment effects, other policy areas (Wave 2)

(1)

(2)

Immigration State intervention

Support immigration

$-0.30^{\text {*t+x }}$

$(0.018)$

Treatment (pro-immigration)

$-0.00032$

$(0.019)$

Treatment*Support Imm

$0.40^{\text {*** }}$

$(0.026)$

Support state intervention

$-0.25^{\star \star \star ~}$

(0.028)

Treatment (pro-state intervention)

$-0.20^{\star \star \star x}$

(0.034)

$0.45^{\text {** }}$

Treatment* Support state intervention

(0.039)

$0.61^{\star \star *}$

Constant

$0.52^{* \star \star}$

(0.025)

$N$

(0.013)

828

$R 2$

.19

.24

Note: standard errors in parentheses; ${ }^{*} p<0.10,{ }^{* \star} p<0.05,{ }^{* \star} p<0.01$.

Source: authors' construction. 